Jurnal Humanitas

Vol. 6 No. 2, Juni 2020, hal. 119-131

\title{
Kolaborasi Majalah dan Teka-Teki Silang Sebagai Media Pembelajaran Inovatif Sejarah (Manis)
}

\author{
Martin Rizaldi $^{1 *}$, Didit Ditya Fritambiradi ${ }^{2}$, Erlangga Bagus Febrianto ${ }^{3}$, dan Lailatul \\ Abid Fadillah ${ }^{4}$ \\ 1,2,3,4 Universitas Negeri Malang \\ 1*martin.rizaldi.1907316@students.um.ac.id
}

\begin{abstract}
Abstrak
Permasalahan yang sering dihadapi guru sejarah dari dulu hingga sekarang ialah minat belajar peserta didik yang kurang dan cepat merasa bosan. Siswa cenderung lebih pasif karena merasa cara pembelajaran yang dilakukan kurang begitu menarik. Beberapa metode pembelajaran telah dilakukan untuk mengantisipasi permasalahan tersebut namun sering kali peserta didik masih kurang bersemangat. Artikel ini bertujuan membahas lebih dalam mengenai pemanfaatan majalah dan teka teki silang yang diharapkan dapat menumbuhkan semangat belajar peserta didik khususnya pembelajaran sejarah. Artikel ini menggunakan metode penelitian kajian pustaka dan pengumpulan data menggunakan angket. Dalam artikel ini peneliti menawarkan solusi menghadapi permasalahan tersebut dengan menggunakan media pembelajaran pemanfaatan majalah serta evaluasi menggunakan teka teki silang online.
\end{abstract}

Kata Kunci: Majalah; Pembelajaran Sejarah; Teka-Teki Silang

\begin{abstract}
The problem that is often faced by history teachers from the past to the present is the students' lack of interest in learning and they feel bored quickly. Students tend to be more passive because they feel the way the learning is carried out is less attractive. Several learning methods have been carried out to anticipate these problems, but often students are still lacking enthusiasm. This article aims to discuss more deeply about the use of magazines and crossword puzzles which are expected to foster students' enthusiasm for learning, especially learning history. This article uses literature review research methods and data collection using a questionnaire. In this article, the researcher offers a solution to these problems by using learning media using magazines and evaluating using online crossword puzzles.
\end{abstract}

Keywords: Magazines; History Learning; Cross Puzzle

\section{Pendahuluan}

Perkembangan teknologi dan ilmu pengetahuan yang semakin maju mempunyai pengaruh besar pada segala bidang kehidupan manusia, terutama dalam bidang pendidikan. Untuk mencapai tujuan pendidikan yang secara efektif dan efisien maka itu 
Jurnal Humanitas

Vol. 6 No. 2, Juni 2020, hal. 119-131

semua tidak terlepas dari kemajuan teknologi dan ilmu pengetahuan. Pada zaman yang telah modern seperti ini sistem pembelajaran dalam pendidikan sudah tidak sama lagi seperti dahulu, saat ini pengajar dituntut untuk membuat pembelajaran yang terkesan lebih menarik bertujuan agar merangsang dan memotivasi siswa dalam mengikuti kegiatan pembelajaran. Oleh sebab itu, untuk mencapai tujuan dari pembelajaran pengajar memanfaatkan teknologi informasi untuk menciptakan sebuah alat bantu yang disebut dengan media pembelajaran.

Dengan adanya media pembelajaran tersebut siswa harus turut berperan dalam proses pembelajaran tidak hanya sebagai penerima pesan, tetapi juga sebagai komunikator untuk menyampaikan pesan. Dengan begitu, dapat terjalinnya proses komunikasi sebagai peningkatan efektifitas pencapaian tujuan dari pembelajaran. Dan guna meningkatkan efektifitas dalam pencapaian tujuan pembelajaran, pengajar dapat memanfaatkan media untuk mengembangkan berbagai model pembelajaran secara kreatif dan inovatif sebaik mungkin, agar proses pembelajaran tidak terasa menjadi kegiatan yang membosankan. Maka dari itu, dalam melaksanakan proses pembelajaran pada sistem pendidikan media pembelajaran memiliki peran yang sangat begitu penting. Berdasarkan dari hasil angket yang kami sebarkan, sebanyak 24 responden sudah mengisi masih sering menggunakan media powerpoint dalam proses pembelajaran dengan presentase sebesar 58,3\%. Tetapi, hampir Sebagian dari mereka lebih menyukai proses pembelajaran melalui media berupa game dengan presentase mencapai 50,0\%. Maka dari itu, kami memilih akan mengembangkan proses pembelajaran yang menarik dan menyenangkan melalui media pembelajaran berbasis game.

Rumusan masalah yang diajukan dalam mengkaji kolaborasi majalah dan teka-teki silang sebagai media pembelajaran inovatif sejarah dapat dijelaskan yaitu; 1) Apa pengertian dan kelebihan dari majalah dan teka-teki silang; 2) Apa saja fitur yang ada dan bagaimana sistem kerja dari aplikasi pembuat majalah Corel Draw X5 dan teka-teki silang; 3) Bagaimana cara mengaplikasikan majalah dan teka-teki silang dalam proses pembelajaran. Dengan tiga rumusan masalah tersebut diharapkan mampu untuk menjawab ketertarikan penulis tentang Kolaborasi Majalah dan Teka-Teki Silang sebagai Media Pembelajaran Inovatif Sejarah. Artikel ini bertujuan untuk mengetahui pengertian dan kelebihan dari majalah serta fitur-fitur dan sistem kerja dari aplikasi pembuat majalah 
Jurnal Humanitas

Vol. 6 No. 2, Juni 2020, hal. 119-131

Corel Draw X5 dan untuk mengetahui cara mengaplikasikan majalah dan teka-teki silang dalam proses pembelajaran.

\section{Metode Penelitian}

Metode dalam penelitian ini menggunakan metode kajian pusaka. Menurut Setyosari (2016) yang dimaksud dengan metode kajian pustaka adalah metode penelitian yang menggunakan sumber referensi dari buku dan jurnal. Sedangkan menurut Nazir (1988) studi pustaka didefinisikan sebagai teknik pengumpulan data dengan menelaah buku, literatur, catatan maupun berbagai laporan penelitian yang memiliki kaitan dengan masalah yang ingin dipecahkan. Sehingga berdasarkan uraian tersebut, metode yang digunakan dalam proses pengumpulan data pada penelitian ini dilakukan dengan menelaah dan mengeksplorasi beberapa buku, jurnal, dan dokumen baik cetak maupun elektronik yang dianggap relevan dengan kajian yang dilakukan.

\section{Hasil dan Pembahasan}

\section{Majalah dan Teka-Teki Silang Online}

Menuru Khazali media cetak merupakan suatu media yang terdiri atas gambar, foto, tata warna dan lembaran-lembaran yang berisikan sejumlah kata. Media ini lebih mengutamakan pesan-pesan visual yang terdapat didalamnya dan media ini terbagi dari beberapa jenis, contohnya majalah dan surat kabar (dalam Hagijanto, 1999). Adapun menurut Andrian majalah adalah media cetak yang mempunyai karakteristik seperti isi yang lebih dalam terperinci dan lebih detail dibanding dengan surat kabar, dan isi dari majalah tersebut tidak hanya menampilkan cerita dari berbagai kejadian yang terdapat unsur tekanan agar menghibur dan mendidik (dalam Hasian \& Adam, 2019).

Berdasar sekian banyak majalah yang sudah ada, kebanyakan majalah tersebut berisikan kisah perjalanan, peliputan penyuluhan, peliputan masalah dan pendirian penulisnya yang dilengkapi dengan foto atau gambar ilustrasi. Majalah lebih mengutamakan kemenarikan dari bahan isinya dibanding dari kebaharuannya. Majalah ini dirasa cukup mampu untuk menjadi sebuah media pembelajaran, karena memiliki beberapa karakteristik yang dapat membantu dalam menunjang proses pembelajaran. Menurut Ardianto \& Erdinaya (dalam Suprihatin, 2012) ada beberapa karakteristik yang terdapat pada majalah, antara lain: 
Jurnal Humanitas

Vol. 6 No. 2, Juni 2020, hal. 119-131

1. Terdapat penyajian isi yang lebih dalam

Proses penerbitan majalah yang cukup lama membuat para penulis mempunyai waktu yang agak panjang untuk menganalisis suatu dari peristiwa, sehingga informasi yang disajikan dapat dibahas secara lebih dalam. Analisis beritanya dapat dipercaya dari berdasarkan buku referensi yang sesuai atau relevan dengan peristiwa tersebut.

2. Nilai aktualisasi atau kebaharuan lebih lama

Sebuah majalah harus mempunyai nilai aktualisasi (kebaharuan) dalam rentang waktu yang lama seperti pada proses pernebitannya, hal itu agar majalah tersebut tidak dianggap sebagai majalah usang.

3. Memiliki lebih banyak gambar dan foto

Selain menyajikan berita yang mendalam, pada setiap halaman majalah dapat juga ditampilkan gambar dan foto dengan ukuran besar serta berwarna, tentunya juga dibuat dengan kertas yang berkualitas baik pula.

4. Cover menjadi sebuah daya tarik

Cover atau sampul majalah dapat menjadi daya tarik trendier dari majalah tersebut, karena dibuat dengan berwarna menggunakan kertas yang bagus.

\section{Aplikasi Pembuat Majalah (Corel Draw X5)}

Menurut Ekopuspo (dalam Somad \& Andipurnama, 2012) Software Corel Draw $X 5$ adalah perangkat lunak yang berfungsi sebagai media pengolahan gambar berbasis vektor. Karena memiliki beberapa keunggulan dan penggunaan aplikasi Corel Draw X5 yang relatif cukup mudah, menjadikan aplikasi ini sering digunakan untuk penerbitan dekstop, advertising serta bidang lainnya yang membutuhkan proses visual. Corel Draw X5 memiliki keistimewaan sebagai media editing grafik vektor yang memiliki hasil akhir yang bagus dengan proses sederhana tetapi tidak kalah dengan hasil akhir dan kualitas dari gambar berbasis raster atau bitmap. Menurut Ekopuspo (2011: 1) dalam Suprihatin (2012) terdapat beberapa keunggulan aplikasi Corel Draw X5 dibandingkan dengan aplikasi desain lainnya, sebagai berikut:

1. Corel Draw sangat cocok untuk mengkolaborasi antara teks dengan gambar.

2. Lebih mudah dalam penggunaannya daripada aplikasi grafis lainnya.

3. Kemudahan dalam mencari tutorial serta tips penggunaan dan pemakaian software Corel Draw karena memiliki komunitas dan forum diskusi yang banyak serta beragam. 
Jurnal Humanitas

Vol. 6 No. 2, Juni 2020, hal. 119-131

Sistem Kerja dari Corel Draw khususnya Corel Draw X5 sangat mudah. Beberapa langka-langkah yang harus dilakukan dalam mengoperasikan Corel Draw diantaranya : 1. Langkah pertama yaitu membuka software Corel Draw X5, setelah terbuka akan muncul tampilan seperti gambar berikut ini.

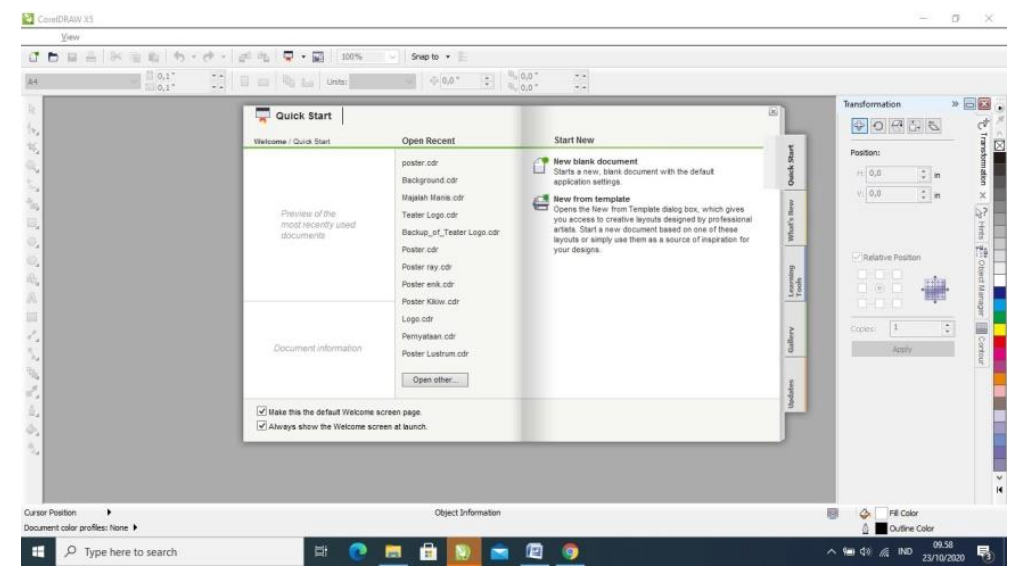

2. Setelah itu pilih New Blank Document untuk membuat file baru yang sesuai dengan software Corel Draw X-5. Setelah memilih New Blank Document akan muncul menu Popup Create New Document seperti gambar dibawah ini.

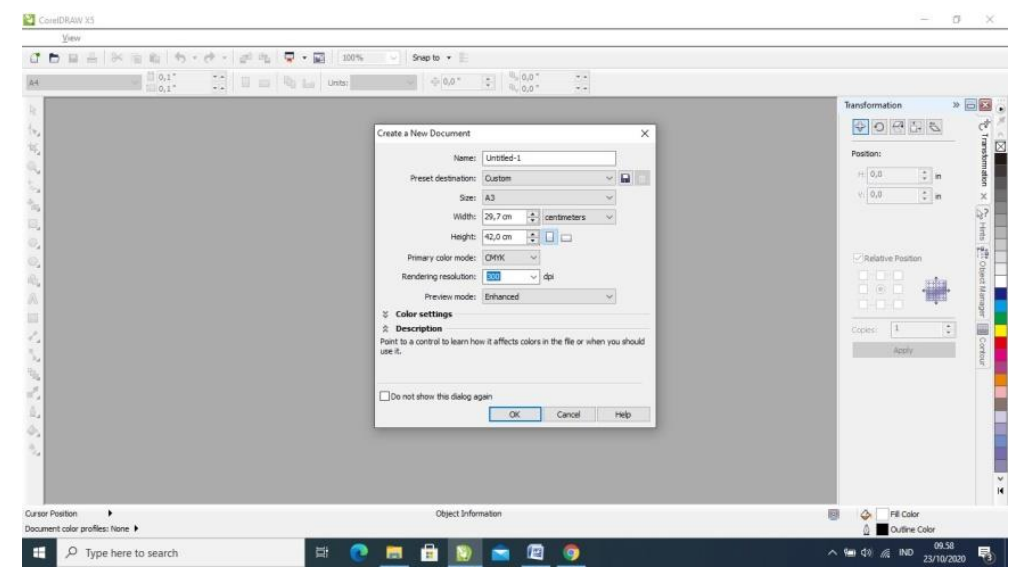

3. Dalam menu Popup Create New Document banyak yang harus diatur atau kita tentukan sesuai dengan yang akan digunakan sebelum melakukan pekerjaan. Ada beberapa yang harus kita ketahui yang diantaranya:

a. Kolom Name : Pada kolom ini berfungsi untuk memberikan nama file untuk pekerjaan yang akan dilakukan 
b. Kolom Preset Destination : Pada kolom ini berfungsi untuk menentukan mode warna yang akan digunakan baik RGB ataupun CMYK dan juga untuk menentukan pengaplikasian setelah pekerjaan selesai, hasil akan digunakan untuk dicetak atau hanya tetap berupa file. Pemilihan warna disini sangat penting, namun untuk awal pilih saja custom.

c. Kolom Size : kolom size berfungsi untuk mengatur luas bidang pekerjaan yang dibutuhkan. Corel Draw sudah mengatur otomatis berbagai jenis ukuran kertas, sehingga memudahkan kita untuk memilih.

d. Kolom Widht dan Height : Kolom weidht dan height pada dasarnya berfungsi untuk mengatur ukuran yang akan kita gunakan, weidht digunakan untuk mengatur lebar dan height digunakan untuk mengatur tinggi. Cara untuk mengaturnya yaitu dengan mengetikan angka ukuran yang akan digunakan atau juga bisa menggunakan panah scroll ke atas dan ke bawah yang ada disisi kanan kolom. Disisi kanan tombol weidt dan height terdapat satu lagi tombol yang berfungsi untuk mengatur satuan ukuran, contoh gambarnya seperti ini.

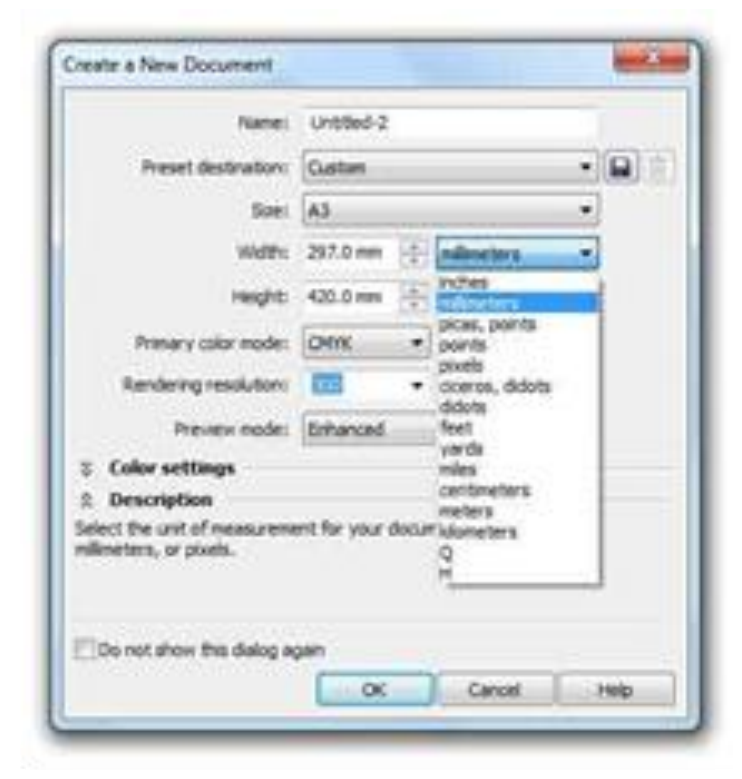

e. Kolom Primary Color Mode : kolom ini berfungsi untuk mengatur warna dasar yang akan digunakan, menggunakan empat warna CMYK atau tiga warna RGB.

f. Kolom Rendering Rosulution : pada kolom ini disarankan untuk memilih 300 dpi, sebagaimana yang sudah tersetting otomatis di software Corel Draw X5.

g. Kolom Preview Mode : pada kolom ini pilih saja enhanced untuk tampilan monitor yang maksimal. 
Jurnal Humanitas

Vol. 6 No. 2, Juni 2020, hal. 119-131

4. Setelah mengatur semua tekan tombol OK, setekah itu akan muncul lembar kerja seperti gambar berikut.

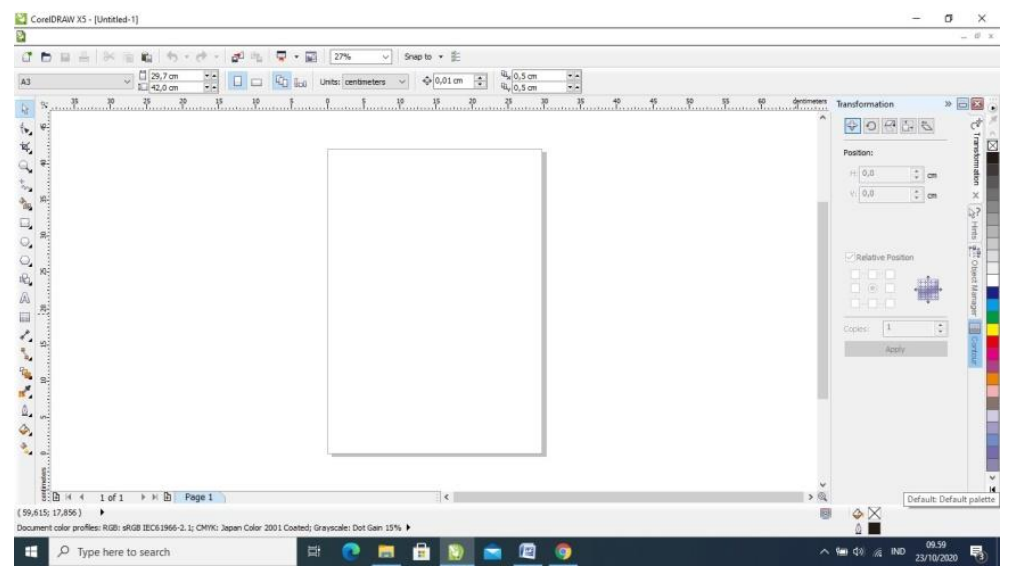

5. Setelah lembar kerja sudah ada bisa menggunakan Rectangle Tool yang ada di Toolbox untuk membuat segi empat yang digunakan untuk media yang akan dbuat atau bisa dengan menekan 2 kali tombol kiri pada mouse. Rectangle Tool dapat dilihat seperti gambar dibawah ini.

6. Setelah sudah

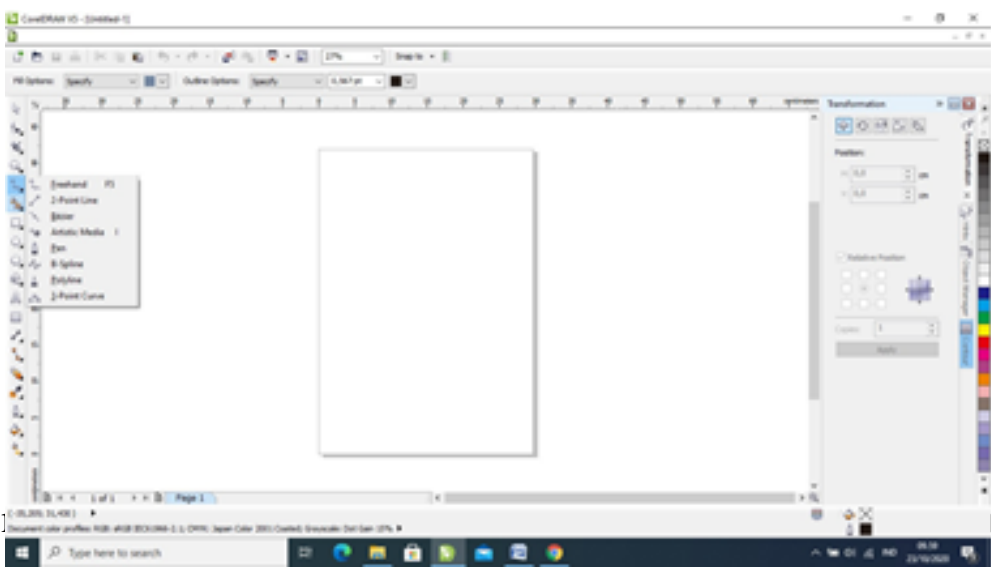
kan dibuat setelah itu menggambar atau membuat objek kurva atau garis kengkung dan garis lurus dalam segment yang dapat dilakukan menggunakan beberapa tool yang ada dibawah ini.

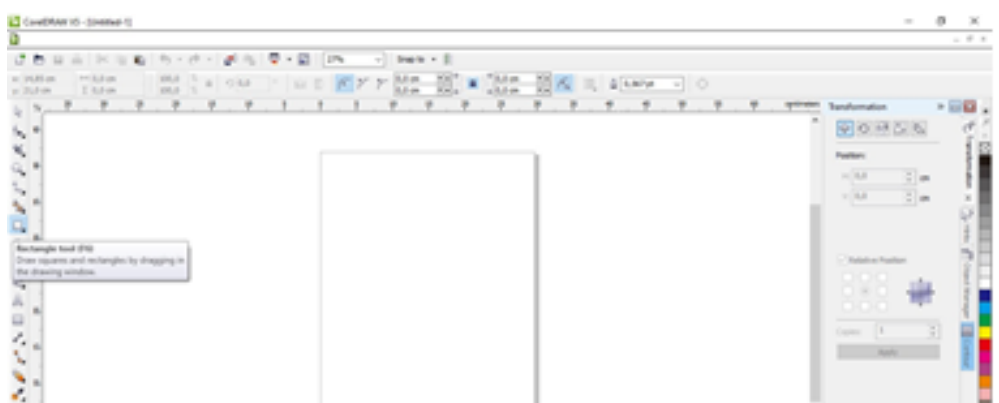


Jurnal Humanitas

Vol. 6 No. 2, Juni 2020, hal. 119-131

7. Selanjutnya bentuk dan desain sesuai keingginan anda sendiri dengan memanfaatkan beberapa tool yang ada di Corel Draw untuk menghasilkan karya yang maksimal. Salah satu contoh hasil yang telah kami buat seperti dibawah ini.

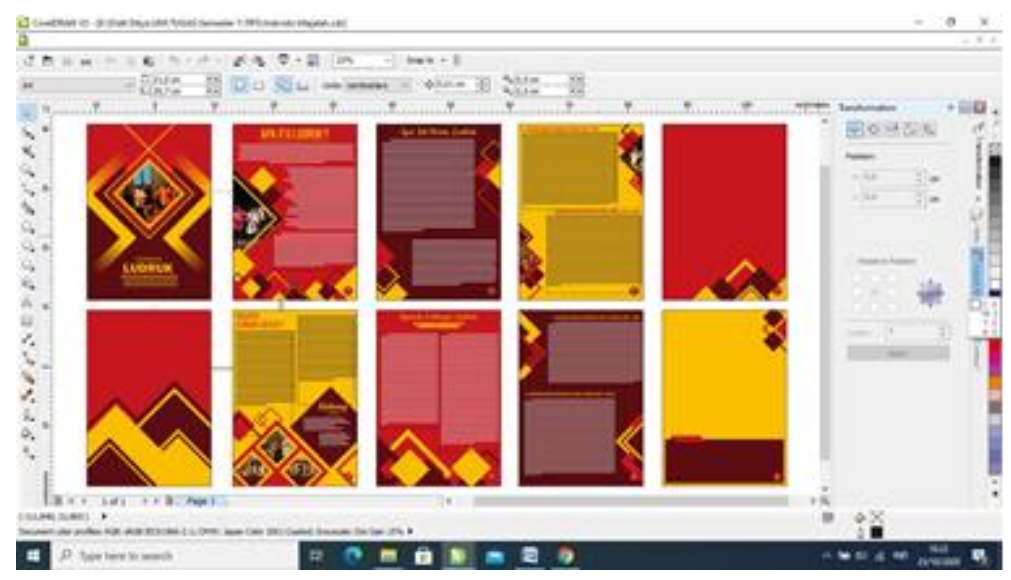

\section{Teka-Teki Silang Online}

Perkembangan teknologi saat ini sudah merambah ke segala macam bidang salah satunya bidang dalam permainan, contoh jelas terjadi kepada teka-teki silang atau lebih dikenal dengan sebutan TTS. Menurut Maryanti \& Kurniawan (2017) teka-teki silang merupakan permainan bahasa yang dilakukan dengan cara mengisi beberapa kotak yang telah disusun baik secara vertikal maupun hirizontral dengan huruf sampai membentuk sebuah kata yang diinginkan. TTS bukan hanya sekedar permainan saja namun dapat juga dimanfaatkan sebagai salah satu media pembelajaran, TTS dapat dibilang sebagai teknik pembelajaran kosakata yang didalamnya mengandung permainan, hiburan, dan dapat dilakukan dengan santai dibebagai macam kondisi dan sangat mudah. Dengan 
Jurnal Humanitas

Vol. 6 No. 2, Juni 2020, hal. 119-131

menggunakan TTS dapat memberikan materi secara dalam dengan cara mudah serta dapat memantik motivasi serta gairah para peserta didik untuk mempelajari berbagai macam kosakata yang berhubungan dengan materi yang disampaikan, sehingga materi lebih mudah untuk diingat dan menjadikan pembelajaran yang berkesan dan tidak mudah untuk dilupakan sebagai salah satu cara belajar yang cukup unik.

Pemainan teka-teki silang mempunyai beberapa kelebihan, seperti yang disampaikan (Imron, 2019) yang diantaranya:

1. Mencegah Demensia yang mana Demensia merupakan kondisi penurunan terhadap kemampuan otak manusia yang mana jika dibiarkan bisa mengakibatkan penyakit pikun hingga penyakit Alzheimer.

2. Meningkatkan kemampuan verbal, jika sesorang belum bisa menyelesaikan TTS ia akan terus mencari apa perbedaan makna kata dari kalimat petunjuk yang ada sampai TTS dapat terselesaikan.

3. Melatih seseorang untuk dapat menyelesaikan masalah karena dengan permainan TTS peserta didik mampu melihat sebuah informasi yang dijadikan sebagai petunjuk dan dapat diterjemahkan menjadi sebuah jawaban.

4. Permainan TTS dapat digunakan sebagai cara ampuh untuk melatih otot-otot dalam otak manusia dalam menangkap pola, hal tersebut berguna karena manusia cenderung menyukai mencari pola dikarenakan pola membrikan struktur dari kehidupan yang mana dari berbagai hal yang berbeda menjadi satu kesatuan.

5. Memeberikan rasa tenang, bermain TTS dapat membantu menurunkan tekanan pikiran seseorang. TTS dapat disebut juga sebagai media rekreasi serta meditasi.

6. Memberikan rasa senang, jika sesorang dapat menemukan jawaban dari TTS yang dimainkan. Hal tersebut dapat memicu seseorang menjalani hari dengan rasa yang positif.

Salah satu situs yang meyediakan pembuatan TTS online yaitu Propofs. Permainan teka-teki silang profosf ini merupakan salah satu cara terbaik dalam membuat game interaktif untuk siswa agar tidak bosan dengan cara penyampaian materi yang terkesan monoton. Dalam permainan TTS banyak hal positif yang dapat diambil dan dipetik oleh siswa seperti membangun kosakata serta meningkatkan kamampuan kognitif dan meningkatkan keterampilan otak para siswa. Cara kerja proprofs terbilang mudah dengan 
Jurnal Humanitas

Vol. 6 No. 2, Juni 2020, hal. 119-131

hasil yang lumayan bagus, berikut merupakan langkah-langkah dalam pembuatan permainan teka-teki silang menggunakan situs proprofs.

1. Langkah pertama yaitu akses situs http://www.proprofs.com/games/ seperti gambar di bawah ini.

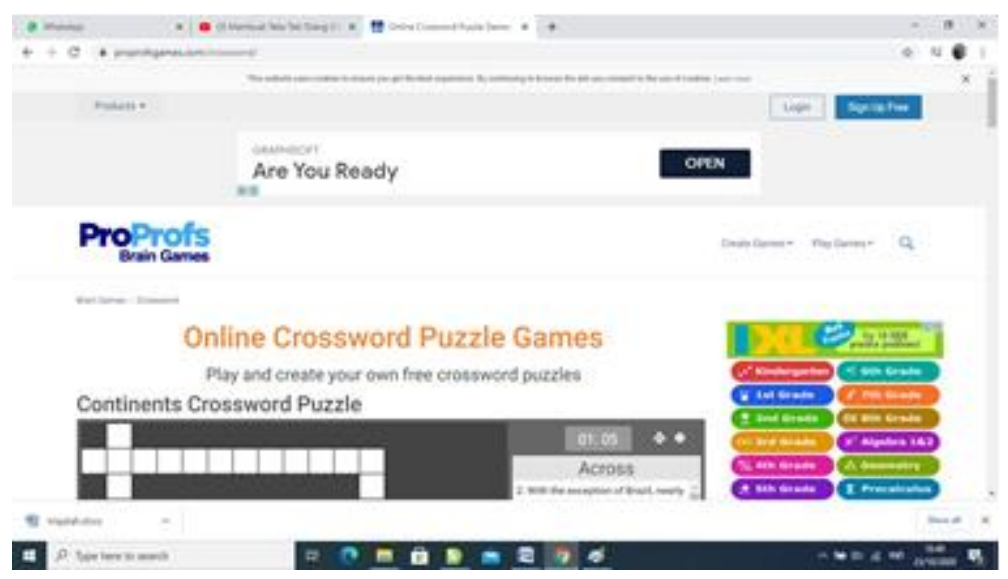

2. Langkah selanjutnya yaitu masuk halaman login, jika belum mendaftar lakukan pendaftaran akun terlebih dahulu dengan menekan sign up.

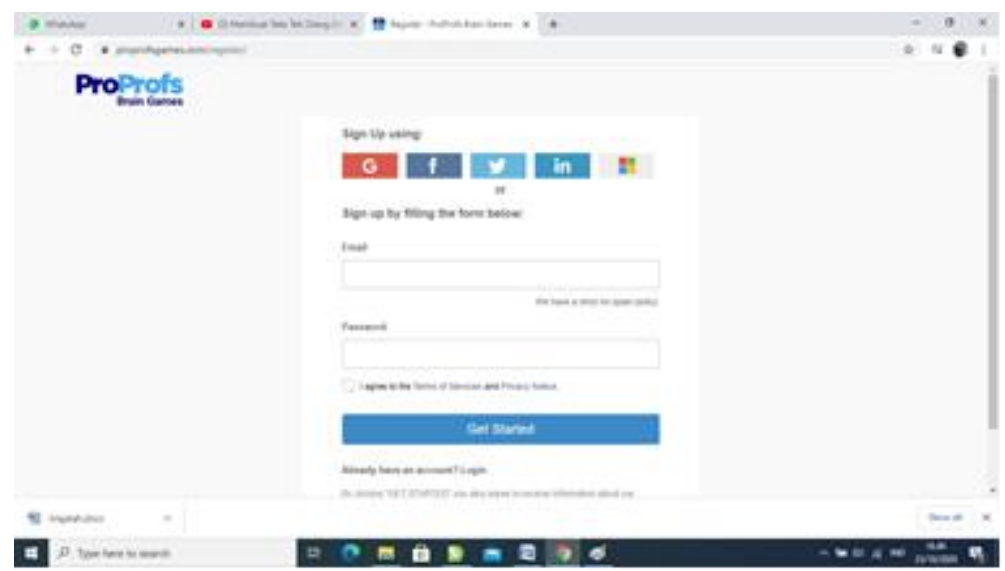

3. Setelah mendaftar dan berhasil untuk masuk kedalam situs lalu pilih Create Games Crossword Puzzle Gamei seperti gambar berikut ini. 
Jurnal Humanitas

Vol. 6 No. 2, Juni 2020, hal. 119-131

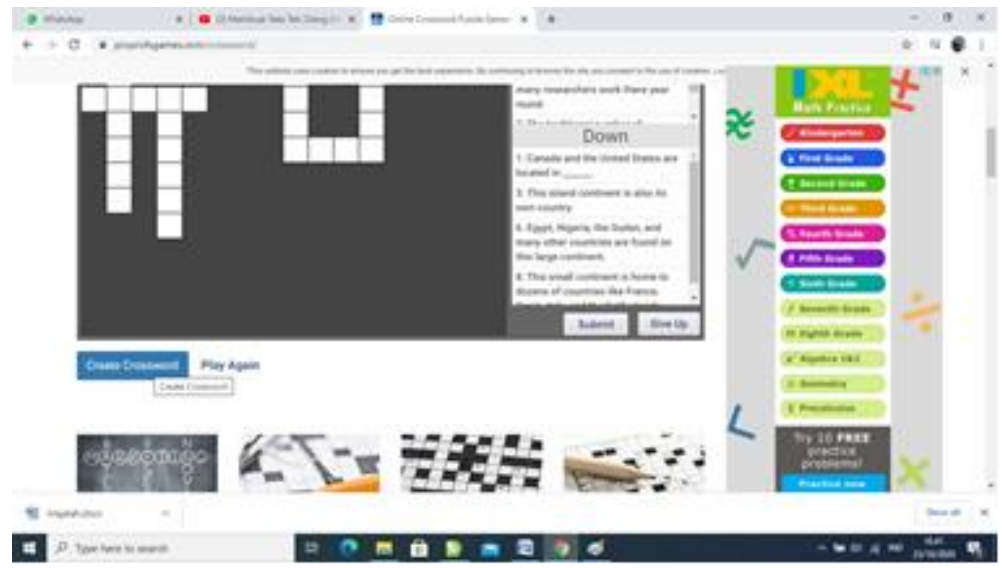

4. Setelah menekan Create Crossword lalu buatlah game teka-teki dengancara mengisi kolom yang telah disediakan sesuai dengan keinginan anda.

Name : Judul permainan anda.

Deskripsi : Kompetensi dasar permainan edukatif anda.

Word : Jawaban dan ditulis tanpa spasi

Hint : Pertanyaan atau kata bantu untuk menemukan jawaban.

Add New Word : Untuk menambah kolom pertanyaan.

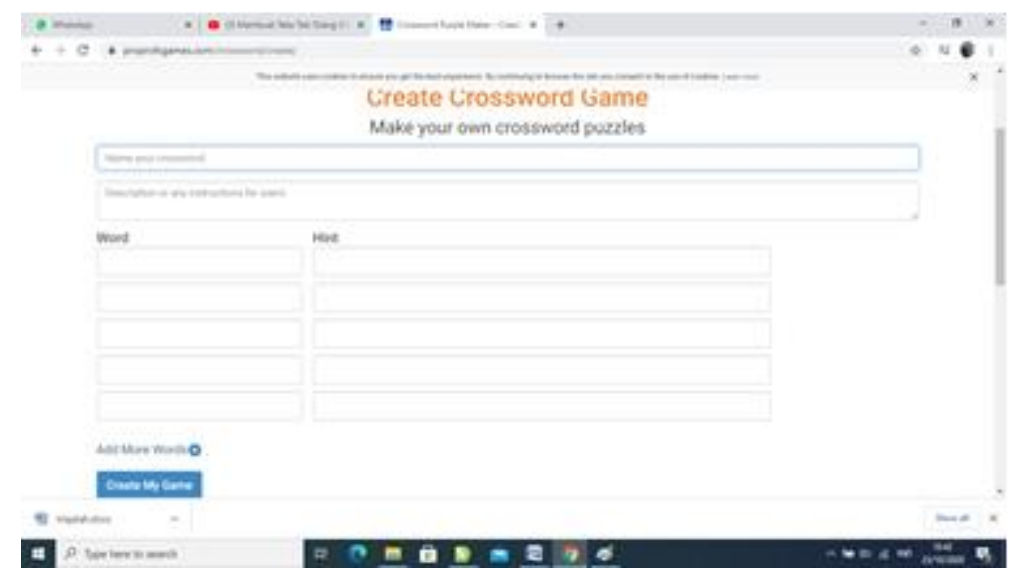

5. Setelah mengisi semua kolom, langkah yang terakhir yaitu menekan tombol create my game dan permaian siap dimainakn. Siswa dapat mengakses dengan cara membagikan tautan ke para siswa. 
Jurnal Humanitas

Vol. 6 No. 2, Juni 2020, hal. 119-131

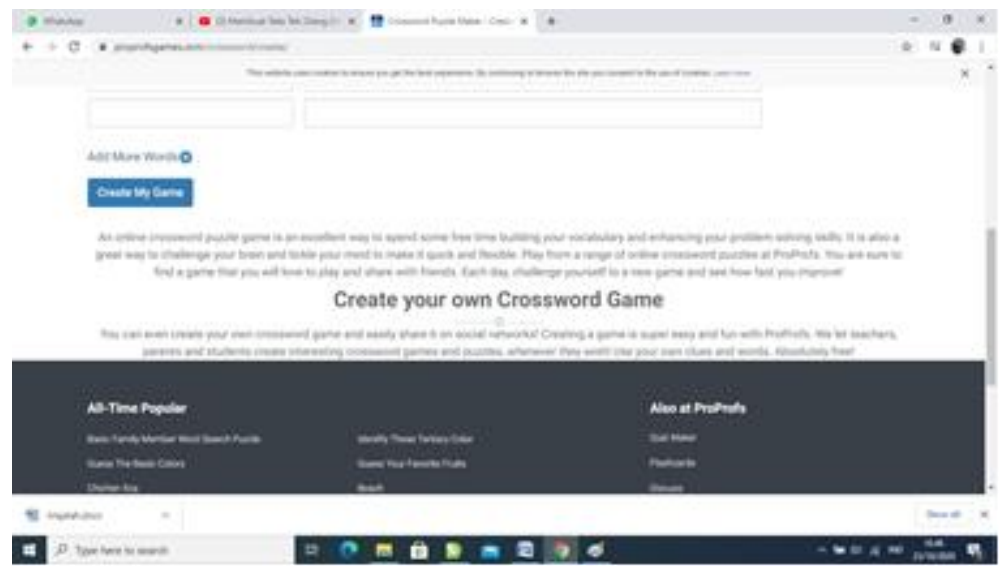

\section{Cara Mengaplikasikan Majalah \& TTS dalam Proses Pembelajaran}

Media pembelajaran majalah dapat diterapkan kedalam dua metode, yang pertama dengan menggunakan metode cetak dan yang kedua menggunakan media online. Metode cetak dapat direalisasikan dengan cara mencetak majalah sesuai dengan jumlah peserta didik dan dibagikan kepada masing-masing peserta didik. Sedangkan metode online dapat dilakukan dengan cara mengunggah majalah ke internet bisa menggunakan Google Drive, Scribd, ataupun situs web berbagi dokumen lainnya. Metode online ini dilakukan selain menghemat biaya dan waktu juga digunakan sebagai salah satu upaya ikut dalam kampanye paperlees dimana usaha untuk meminimalisir penggunaan kertas. Setelah peserta didik mendapatkan majalah diharapkan peserta didik untuk mempelajari isi dari meteri yang ada, majalah dapat digunakan sebagai media bantu selain buku teks dan juga buku LKS atau lembar kerja siswa. Selanjutnya, jika peserta didik sudah memahami isi materi yang disampaikan dapat langsung mengisi evaluasi berupa permainan teka-teki silang online yang dapat diakses melalui barcode yang sudah disiapkan.

\section{Kesimpulan}

Majalah adalah media cetak yang mempunyai karakteristik seperti isi yang lebih dalam terperinci dan lebih detail dibanding dengan surat kabar, dan isi dari majalah tersebut tidak hanya menampilkan cerita dari berbagai kejadian yang terdapat unsur tekanan agar menghibur dan mendidik. Majalah memiliki kelebihan trendier dibandingkan dengan program lain, seperti terdapat penyajian isi yang lebih dalam, nilai aktualisasi atau kebaharuan lebih lama, memiliki lebih banyak gambar dan foto dan cover 
Jurnal Humanitas

Vol. 6 No. 2, Juni 2020, hal. 119-131

menjadi daya tarik. Selain itu, ada juga teka-teki silang yang dapat dimanfaatkan sebagai salah satu media pembelajaran. Teka-teki silang berisi permainan dan hiburan yang dapat dilakukan dengan santai dan secara mudah. Dengan menggunakan TTS dapat memberikan materi secara dalam dengan cara mudah serta dapat memantik motivasi, sehingga materi lebih mudah untuk diingat dan menjadikan pembelajaran yang berkesan dan tidak mudah untuk dilupakan sebagai salah satu cara belajar yang cukup unik.

\section{Daftar Rujukan}

Andrian D. Hagijanto. (1999). White Space Dalam Iklan Di Media Cetak. Nirmana, 1(2), 60-70.

Hasian, H., \& Adam, D. (2019). Analisis Perkembangan Elemen Desain Cover Majalah Gogirl!. Magenta| Official Journal STMK Trisakti, 3(2), 506-520.

Imron, A. I. (2019). Game Online Teka-Teki Silang dengan Software Hot Potatoes 6 untuk Mendukung Pembelajaran Ilmu Hadis. Jurnal Living Hadis, 4(1), 159-180.

Maryanti, S., \& Kurniawan, D. T. (2017). Implementasi Pemanfaatan Media Teka Teki Silang (Tts) Online Dalam Matakuliah Neurosains Untuk Mahasiswa Calon Guru Raudhatul Athfal (RA). AWLADY: Jurnal Pendidikan Anak, 3(2), 124-138.

Memenuhi, U., Persyaratan, S., \& Derajat, M. (2012). Perpustakaan. Uns.Ac.Id Digilib.Uns.Ac.Id.

Nazir, M. (1988). Metode Penelitian. Jakarta: Ghalia Indonesia.

Setyosari, H. P. (2016). Metode Penelitian Pendidikan \& Pengembangan. Jakarta: Prenada Media.

Somad, P., \& Andipurnama, G. (2012). Pembelajaran Program Aplikasi Corel Draw X4 dalam Meningkatkan Keterampilan Desain Gratis Poster Siswa Tunarungu. Jassi Anakku, 11(1), 48-57.

Suprihatin, C. (2012). Pengembangan Media Pembelajaran Berupa Majalah Untuk meningkatkan Minat Baca Siswa SMP pada Materi Cahaya. PROSIDING : Seminar Nasional Fisika dan Pendidikan Fisika, 3(5), 495-505. 